\title{
Applying music-and-movement to promote agency development in music education: a case study in a special school
}

Keywords: agency, special education schools, Dalcroze, music-and-movement, case study

\begin{abstract}
In this article, we describe the development of agency in one student with special needs through Dalcroze-based music-and-movement activities. The case study was conducted in the context of classroom music education in a special school. The data was produced via a teaching experiment (from August 2015 to March 2016), in which a group $(\mathrm{N}=13)$ of 15- to 16-year-old students participated in added lessons (one lesson per week) provided by the first author. The lessons included a variety of Dalcroze-based activities, such as singing with movement, quick reaction and follow exercises, movement improvisation, body percussion exercises, dances, and relaxation exercises. The data consist of video recordings of the lessons, a research diary, and interviews with teachers, teaching assistants, a therapist, and a specialist in special education. During the teaching experiment, the case student's agency developed from a passive outsider to the active participant and leader. The change in agency was noticed also outside the classroom. The study suggests that using music-and-movement in a music classroom offers possibilities for non-verbal embodied interaction and thereby opportunities for the development of students' agency and autonomy foremost by developing their body and social skills. On a more general level, the article contributes to developing such music education theory and practice that acknowledges the significance of experience in learning music and in embodied interaction, where individuals interact and make sense of the world through non-verbal communication. In addition, this study highlights the strength of such education in supporting the development of the whole human being.
\end{abstract}

\section{Introduction}

The commitment to the principles of equality in education, regardless of gender, religion, ethnicity, ability, or any economic, social, or cultural factor is a necessary condition for a democratic and progressive society (Dewey, 1897, 1916; IPU 1998; Unesco, 1994, 2007). Equality in education is not achieved merely by providing equal resources for each student, but also requires that personal circumstances not be obstacles to educational success (OECD, 2012). This necessitates, among other things, that each learner's characteristics and needs are taken into account and that sufficient attention be given to students with learning difficulties and other educational needs. The increasing number of students with special needs is a current challenge for teachers. Teachers must master educational practices that support each student's learning potential. In music education, the needs and challenges are already recognised (Darrow, 2014; 2018; Darrow \& Adamek, 2017; Laes, 2015, 2017; Ockelford, 2015). Nevertheless, it seems that music education is still short on pedagogical tools with which to enhance the participation, agency, and functional abilities of students with special needs. Therefore, we are interested in exploring how certain pedagogical tools might enhance the participation and 
support the development of agency in music education, and thereby facilitate the growth of learners to fulfill their potentials, both individually and in the society.

In this study ${ }^{i}$, we examine the development of agency in one student with autism spectrum disorder (ASD), more specifically Asperger's ${ }^{\mathrm{ii}}$, in the context of general music education. More precisely, we ask: What kind of development of agency, if any, can be identified in his participation, interaction, and bodily expression in the music-and-movement lessons during one school year? We also aim to enhance discussion about the possibilities of music-and-movement in supporting participation of students with Special Educational Needs (SEN) in music classrooms.

Music-and-movement teaching in this study was based on the Dalcroze approach, which emphasizes the importance of embodied personal experience as the basis of learning music (e.g., Jaques-Dalcroze, 1921/1980; Juntunen, 2016). It integrates body movement (rhythmics), listening (ear-training), and improvisation, and recommends that music is effectively experienced, expressed, understood, and studied through the interaction of sound, sound perception, and movement response, through embodied and multisensory exploration.

Especially from the viewpoint of special education, the strength of Dalcroze teaching is that it enables musical interaction without requiring former musical or instrumental knowledge or skills. In the exercises, students follow and respond to music and to teacher's instructions; move with music and change these movements; interact with others, thus calling for continuous attention (Juntunen, 2002). In the complex interaction, students can practice and develop musical skills (such as the ability to recognize, know, understand, and express musical elements and phenomena, active listening, and improvisation); body skills (body awareness, fine and gross motor skills, coordination, balance, relaxation); social skills (social integration, collaboration, interaction and communication, learning with and from others, respecting others, etc.); as well as such mental capacities as engagement, memory, self-confidence, curiosity, flexibility, and the ability to follow directions, reciprocate actions, and process information. Additionally, the Dalcroze approach includes other educational goals that concern the holistic growth of the human being, the body-mind balance, and overall wellbeing (Juntunen \& Eisenreich, 2019; Juntunen \& Hyvönen, 2004).

\section{Theoretical background}

Even if the aims of music education are primarily in the learning of music, the wider educational goals and benefits of learning through music are widely recognized. This is especially the case in the context of special education which aims at supporting social relations, preparing for full participation in future work life, and achieving the knowledge and skills necessary for citizenship (e.g., Darrow \& Adamek, 2012; Hammel \& Hourigan, 2011). Earlier studies show that music education indeed has the potential to improve general learning skills. For example, music studying and learning improve reading skills (Flaugnacco et al., 2015; Huss et al., 2011; Lamb \& Gregory, 1993; Long, 2014; Overy, 2008; Strait, Hornickel \& Kraus, 2011), motor development, communicative action, and socialemotional engagement with others (see, e.g., Hallam, 2015; 2016; Marsh, Richardson \& Smith, 2009; Whipple, 2004; Wigram \& Gold, 2006).

Interactive group activities with music have proven to be especially beneficial. Such exercises provide opportunities for turn-taking and social reciprocity, joint attention, imitation, empathy, and shared affect, which are typically impaired in individuals with autistic spectrum disorder (Overy \& Molnar-Szakacs, 2009; Scott, 2017; regarding music therapy contexts, see Altenmüller \& Schlaug, 
2015; Geretsegger et al., 2014). Synchronous movements, that is, temporally aligned similar movements between two or more individuals, during musical activities can create a state of social cooperation, a sense of togetherness, and a shared purpose (Kirschner \& Tomasello, 2010; Marsh, Richardson \& Schmidt, 2009). Furthermore, several researchers recommend using embodied musicbased approaches ${ }^{\mathrm{iii}}$ with students with ASD to facilitate various forms of development including communication, social-emotional, and motor development (Kirscher \& Tomasello, 2010; Overy \& Molnar-Szakacs, 2009; Srinivasan \& Bhat, 2013, Tryfon et al., 2017). Also, the case study of HabronJames (2013), who investigated the use of Dalcroze-based music therapy for four children with SEN, suggests that Dalcroze teaching has a positive impact on children's well-being due to the development of both communication skills and a sense of contentment. The study of Srinivasan and Bhat (2013, p. 6) proposes that the 'music and movement games facilitate the social-emotional and behavioral skills in children with ASD'. According to Berger (2015), the ideas of the Dalcroze approach are also transferrable to interventions for the specific kinesthetic and sensorimotor goals of music-based treatment, such as the attainment of sensory and physical coordination, the ability to attend and quickly respond to environmental stimuli, self-expression, and self-awareness. In addition to the improvement of body and musical skills, Dalcroze teaching develops social and communication skills as well as an awareness of personal identity, and agency (e.g., Abril, 2011; Davidson, 2009; Juntunen, 2015; Van Der Merwe, 2015 Wang, 2008).

Defining the concept of agency is a complex task and, as such, well beyond the scope of this article. The notion has been widely studied in sociology (e.g., Bandura, 1986; Giddens, 1984), sociocultural and activity theory (Engeström, Miettinen \& Punamäki, 1999; Vygotsky, 1978), cognitive science (Gallagher, 2000; Lakoff \& Johnson, 1999), philosophy (e.g., Pippin, 2008, Thalberg, 2014; embedded also in Dewey's pragmatism and Merleau-Ponty's phenomenological philosophy), and also music education research (DeNora, 2002; Karlsen, 2011; Laes, 2015).

In general, agency is a capacity for intentional, controlled action, alluding the existence of an entity (Moran, 2018). Our stance concurs with the embodied mind paradigm (see Johnson \& Rohrer, 2007; Lakoff \& Johnson, 1999; Määttänen, 2015; Matyja \& Schiavio, 2013; Maes, 2016; MerleauPonty, 1962; Meynell, 2009; Shapiro, 2010). Therefore, here, agency is understood as an embodied capacity for action in changing relational contexts, through which individuals adapt and accommodate their actions accordingly. It is an ability to use the capabilities that one has in order to make use of opportunities, to interact with others, and to participate in society at large (Koggel, 2009).

Based on Campbell, Meynell, and Sherwin (2009), we identify the following aspects in the embodied notion of agency (Juntunen, 2015). First, agency is close to the notion of subjectivity, which in this case, is congruent with the concepts of self and authorship, being not merely psychological but also embodied (Mackenzie, 2009, p. 114). In other words, making sense of oneself involves perceiving oneself not as a thinking subject but as an 'embodied agent'; it is not a matter of 'I think' but of 'I can' (Merleau-Ponty 1962, p. 159). The reflective dimension of agency can be called 'sense of agency' (Gallagher, 2012; Tsakiris, Longo \& Haggard, 2010) or 'agentive self-awareness' (Pacherie, 2010). Accordingly, agency develops in the process of absorbing and incorporating new bodily skills and competencies, which in turn changes our ways of acting, perceiving, and thinking (see, e.g., Yakhlef, 2010). Secondly, agency develops through intersubjective communication, that is, in interaction with others. It is mediated by and responsive to one's relationships with other people, one's social situation, and social and cultural representations and practices (Mackenzie, 2009, p. 118). Thirdly, emotions are an essential element of our development toward autonomous ways of being 
and an important dimension of agency. This is also agreed upon by emotion theorists (Pessoa, 2008, 2009; Stocker \& Hegeman, 1996), who emphasize the role of emotion in motivating action and directing attention. As Burrow (2009) states, emotions mediate our expressive attempts to incorporate and make good judgements in the situations in which we find ourselves, thus leading to autonomy, i.e., the ability to make decisions and to put them into practice. According to Meyers (2004), the development of autonomy is the process of developing competencies such as coordinated reasoning, imagination, and volition. Meyers calls these agentic skills 'autonomy competency' (2004, xvii), through which subjects become autonomous through interacting with others by developing autonomy in and through relationships of interdependence and dependence. Concrete contexts have an impact on autonomy as well in that they 'may undermine or enhance choice and action' (Burrow, 2009, p. 133).

\section{Methodological choices}

We use a range of qualitative research methods, combining case study research (Yin, 2003; Stake, 1995), ethnography (Atkinsonet et al., 2001), hermeneutic phenomenology (van Manen, 2016), and narrative analysis (Polkinghorne, 1995). The case study and ethnographic research methods provide a broad framework for the data acquisition of this study. Hermeneutic phenomenology and narrativity form the basis for the data analysis and interpretation.

\section{The teaching experiment}

A teaching experiment was organized by the first author to examine the potential of Dalcroze-based music-and-movement teaching in fostering the development of agency among students with SEN. The aim of the teaching experiment was to support the development of agency by facilitating active musical participation and interaction. The experiment took place in a special education school in Northern Finland over one school year, from September 2015 to March 2016. Along with the students $(\mathrm{N}=13$, from two classes), two classroom teachers and their teaching assistants participated in the teaching experiment and study. The participating classes were chosen based on the classroom teachers' interest levels in the study, as well as timetable factors. Participants had no previous experience of Dalcroze-based music lessons.

The choice of teaching approach was based on earlier studies suggesting several positive impacts, as discussed above, and also on the first author's earlier positive experiences when applying Dalcroze approach in her music teaching in the school in question from 2002 to 2013. During that time, she noticed that in a regular music teaching practice many students got frustrated and exhibited a low self-esteem regarding their musicianship since they lacked the required skills to concentrate and play the instruments. Music-and-movement exercises offered the students an easy way to participate in music and supported their concentration on and potential in music learning.

The teaching intervention took place in a large classroom, where the classroom teachers and their teaching assistants participated in the music-and-movement activities with the students. The lessons, altogether 21, were added to the school curriculum and included a variety of typical Dalcrozian music-and-movement activities, not pursued in the regular music lessons. These activities included singing with movement, follow and quick reaction exercises (the students responding in movement to music, others' movements or to musical cues, see Juntunen 2002), body percussion exercises, movement expression (drama) and improvisation, dances, and relaxation exercises. The 
45-minute lessons followed usually the same structure: an introduction in a circle, a warm-up exercise, exercises related to the musical topic of the lesson, and relaxation. The lesson plans were not strictly fixed in advance but evolved according to student responses and needs, and the reflections of the teacher. Some of the students' favourite exercises, such as a chain dance and tennis ball massage, were repeated several times during the teaching experiment. Musical topics included tempo, harmony, and metrics. The goal was also to develop students' body awareness, (mind) body skills as well as communication and social skills. In the lessons, students listened to, explored, and expressed their musical experiences (either live music played and improvised by the teacher-researcher, or recorded music) through movement and gestures, and thus also manifested their musical understanding.

Exercises were mostly performed in pairs or in a large group. In addition, different props, such as tennis balls, were utilised to make the musical phenomena more concrete (for example, students bounced the ball in tempo, or rolled it in a certain meter). In the exercises students practiced motor and other body skills, social interaction, non-verbal communication, movement expression, as well as group dynamics (e.g., leadership). In overall, the goals of the teaching experiment resonate with those of music therapy, but the teaching experiment cannot be considered as such. The teacherresearcher's extensive background in special education, through studies in special education and courses included in music teacher education, as well as earlier experiences of teaching in special school assured her expertise in this field. Furthermore, the therapeutic aspects were present through the collaboration with the specialist of special education and Noah's therapist.

\section{The case student}

In this article, we report our findings regarding the development of agency in one participant, here called Noah. He was chosen as the case student because during the first lessons of the teaching experiment, considerable changes were observed in his agency as compared to the other participating students. This case study represents "intensive analysis of a single unit", where our goal is "to understand a larger class of similar units' (Seawright \& Gerring, 2008, p. 296) in the context of music education.

When the project started, Noah was a 15-year-old male student diagnosed with Asperger's (AS), which is considered a part of the autistic spectrum (Matson \& Sturney, 2011). Noah's position in the spectrum falls more toward the high-functioning end. In the beginning of the teaching experiment, Noah displayed inability in multiple nonverbal behaviour, such as eye-to-eye contact. He was not able to interact with other students. Yet, he listened to what happened in the classroom. In addition, Noah displayed an inflexible adherence to specific rituals and routines; stereotyped and repetitive motor mannerisms, such as hand flapping and complex body movements; and a persistent preoccupation with certain physical objects of the environment. Based on the descriptions provided by his teachers, their assistants, and an occupational therapist at the beginning of the experiment, Noah had more difficulties in interaction, communication, and imagination than adolescents of his age normally would. He had a need to explore the space around him in concrete ways by intermittently touching the walls or other people in the room and thereby 'grounding himself in the moment and space,' as described by his therapist. His body language displayed non-attendance in the form of turning away from the centres of action. He tended to flap his hands while walking, and his movements were generally small and limited, which is typical of individuals with autism (Bauman, 1992), especially during stimulating or stressful conditions. Noah did not make facial expressions, 
which makes it challenging to identify his emotions. During prior music lessons, Noah had not shown any interest in musical activities nor participated in them.

\section{Ethical concerns}

The ethical questions were addressed according to the standard procedures (TENK, 2012, national guidelines for responsible conduct of research, comparable to those by BERA, 2011). Informational letters describing the study were given to students, their parents, the therapist, the assistants, and the teachers. Signed informed consent forms were obtained from all participants. In addition to the consent letters, the teacher-researcher carefully explained the aim and content of the teaching experiment to the participants and provided information about the research weeks before the teaching experiment started and then again during the project. This notwithstanding, a question remains concerning how we can ensure the students with SEN fully understand to what they are consenting.

The ethical concerns related to involving students with SEN in research challenges both the researchers and the participants. While protecting the rights of the students to be included in research, students must also be protected from potential harm and exploitation. Noah and his parents signed consent forms, and his parents also provided separate permission to interview the therapist and chose Noah as a case student. Furthermore, it was recognized that music-and-movement activities could evoke strong feelings, such as rage, joy, embarrassment, and sadness, and that those would need to be navigated with the utmost discretion and care.

\section{Data collection and analysis}

This article draws on research data consisting of video recordings of the music-and-movement lessons, a research diary, and interviews (with the classroom teachers, assistants, therapist, and specialist in special education). All the music-and-movement lessons were videotaped during the 2015-2016 school year with one video camera. All participating teachers and assistants were interviewed (in-depth semi-structured interviews; e.g., Kallio et al., 2016) three times during the school year, in pairs at the beginning and in the middle, and individually at the end of the teaching experiment. Noah's occupational therapist (who had met with Noah regularly for a three years) was interviewed in January 2016. The specialist in special education (who was not previously familiar with Noah) was consulted after the experiment, in November 2016. Noah was interviewed twice (as were other students). Unfortunately, that data provide little insight into the development of his agency. In the interviews, he was not able to reflect on his experiences, it was often difficult to understand his speech, and his answers consisted of only one or two words, providing little data..

Since Noah could not himself reflect on the development of his agency, the video data and observations became central. This led to methodological questions such as: How is it possible to analyse a person's agency through observation? How can we interpret Noah's actions and understand his embodied experiences? How can we interpret his gestures, bodily positions, stances, participation, and interactivity as manifestations of his agency? Though Noah's own articulations would have been enlightening, analysing the development of agency through observation was considered well founded since we understand agency as a capacity manifested in action. Furthermore, since agency as the underlying capacity for action is not only embedded in the physical environment but manifests in social interaction and social contexts, producing data through the interviews and the research diary appeared similarly well grounded. 
The analysis was mainly based on the video data and the first author's research diary. The interviews with the teachers and assistants, and the remarks made by the therapist and specialist in special education provided support for the analysis and an opportunity for data triangulation (e.g. Carter et al., 2014.) First, the first author watched the transcribed videos and performed an initial coding of Noah's (inter)actions during the lessons. The initial data-driven codes consisted of bodily passivity, bodily activity, rambling, touching, bodily interaction, responsiveness, and initiative as indicators of agency. When analysing the video data, Noah's development of agency was observed in terms of his participation in music-and-movement activities, interaction with others, and ways of responding to others' initiatives, or taking the initiative. The initial analysis of the video data showed how Noah's behaviour gradually changed from bodily passivity to activity and from non-participation to interaction, as the lessons proceeded. Then, based on the video data (with the help of a research diary), the first author chose four classroom events as significant moments (van Manen, 1990, p.10) to illustrate certain phases of agency development (although it is recognized that the development was not completely a linear process).

Next, the interviews and the research diary were analysed using data-based thematic analysis (Braun \& Clarke, 2012). According to Braun and Clarke (2012), data-based thematic analysis is not wed to any pre-existing theoretical framework. In this case, it was an appropriate tool 'for identifying, analysing, and reporting patterns' (Braun \& Clarke, 2006, p. 79) in the rich data. The first author generated initial codes $(\mathrm{N}=38$ for teacher and teaching assistant interviews, $\mathrm{N}=14$ for student interviews) to form data-based basic themes and collated data relevant to each theme. Subsequently, the codes were integrated based on their similarities concerning the chosen extracts. Next, the first author reread the chosen extracts linked to each basic theme and made new groupings of organisational themes $(\mathrm{N}=9)$, refining the themes further into themes that were both 'specific enough to be discrete (non-repetitive), and broad enough to encapsulate a set of ideas contained in numerous text segments' (Attride-Stirling, 2001, p. 392). Finally, the first author arranged the organisational themes into four groups and the following themes were identified: 1) gaining self-confidence and experiencing togetherness, 2) becoming attentive and practicing contact, 3) stepping out of comfort zones and gaining new skills, and 4) obtaining safe proximity. After the thematization, the first author checked if these themes worked in relation to the entire data.

Further, narrative analysis of the classroom events triangulated the video and interview data, the research diary, and the specialist's remarks on the video data, and organized the prior analyses into a coherent whole by synthesizing a description of the development of Noah's agency (see Polkinghorne, 1995). This resulted in describing the development of Noah's agency in the form of four successive episodes. Each episode identifies specific culminations in Noah's development. The episodes are called: (1) the passive outsider and observer, where Noah responds to others' initiatives only occasionally; (2) active agent through temper tantrum, in which Noah participates in group activities while his participation and agency is marked by emotional outbursts; (3) the interactive and expressive participant, where Noah responds to initiatives of others and takes initiative based on them, leading to dialogue; and (4) the active leader and equal participant, in which Noah takes initiative, responded to by the others, and adopts leader and other roles.

\section{The development of Noah's agency}


In what follows, we present four relevant episodes that chronologically illustrate the key phases of the development of Noah's agency, followed by a short reflective analysis of each. In these episodes, the first author is both the teacher and the narrator.

Passive outsider and observer (September 2015)

We (me as a teacher and eight students) are sitting in a circle and listening to Kraftwerk's piece We are the robots. We discuss what kind of images the music evokes in us. Noah is sitting with us, but he has turned away and is not participating. When we stand up and start moving with the music in groups, Noah remains seated. While I explain the following exercise and organize the groups, Noah stands up and walks away. He remains standing far away and watches us moving. Finally, he goes to touch the pillar, leans on it, and stands there with his back to us.

Noah's attitude, as expressed by rejecting engagements in social interaction, turning his back on the other students, and wandering around, during the first music-and-movement lessons was interpreted by the special education specialist as manifestation of insecurity and anxiety in a new situation. The social situation of the music-and-movement activities created a stressful situation for him. He could not find a way to join in and simply escaped from the activities. According to his classroom teacher, he was fully aware of things happening around him, but was still not capable of making the decision to participate. As the teaching assistant described: 'Noah was interested (in music-and-movement activities), but he just was not able to do them. But still, he was always somewhere near, wandering around and touching with his hand and so on'. According to his therapist, teacher and teaching assistant, Noah was lacking his own will and initiative in interaction or classroom situations and needed constant reminding of the task at hand. The therapist reported that staying focused in interaction was challenging for Noah and that improving initiative and communication had been the main goals in his therapy.

However, as the teaching experiment continued, Noah gradually started to show more interest in musical activities and others. Moving in space with others was also considered to be good for him by the teachers and the special education specialist, since it seemingly helped him to listen and to focus the task at hand.

\section{Active agent through temper tantrum (November 2015)}

I start the lesson in a circle, as always, so that everyone will feel included and part of the group. We first discuss some current issues and then start to learn the steps for a dance. Noah stands in his usual place, next to the classroom teacher, who encourages him with her movements and words to participate, while his classmate Alex expresses dislike towards the activity. After learning the steps, we sit down to learn the lyrics of the song accompanying the dance. I play the djembe drum, and we all sing together, except Noah, who seems anguished and starts to retreat. I continue playing, even though I notice his reaction. Soon Noah lays down on the floor and has a very strong, physical fit of rage. He kicks and hits the floor repeatedly. Eventually, he runs to the other side of the room and bangs the bench. He gets everybody's attention. I go and talk to him, without succeeding in calming him down. Because we do not find a solution, he is escorted to his own classroom.

It seems that the contradicting messages, one from his classroom teacher and the other from his friend Alex, towards the lesson activities caused a stressful situation and made Noah anxious. As the teacher noted, 'somehow he was provoked very strongly by the situation'. Also his classroom teacher and 
assistant interpreted the situation as 'not comfortable for him', probably because of the strong expression of dislike from Alex, whom Noah was always strongly looking up to, and also because of the loud djembe sound. Apparently, as his therapist noted, Noah was not able to interpret all the mixed messages of the situation.

As Noah was not able to handle the anxiety in the lesson, he became caught up in emotional tension, which ultimately resulted in an emotional outburst. Although the reaction to it was negative, the outburst was an effort to act in order to resolve the situation, one way or another. For others, this might have meant the interruption of the lesson as Noah's goals were incompatible with that of others albeit they may have been logical to him. As the classroom teacher put it, 'he was enjoying everyone's attention when banging the bench'.

After this rather emotional lesson, Noah's participation continued to be restricted by his physical mannerism, but gradually he succeeded in participating more and more in music-andmovement exercises as well as other school activities. For example, when rehearsing for the independence day ball in the end of November, he surprised everyone by dancing hand in hand with another student, encouraged by his classroom teacher who thought that this kind of social activity, like dance, was good for him, as a socially established and accepted channel for physical contact and coordinated, joint movement. His initiative in dancing activity was noticed also outside the classroom and evoked a lot of wonder among the school staff.

\begin{abstract}
Interactive and expressive participant (February 2016)
We are performing an exercise in pairs that aims at developing kinesthetic awareness. In the exercise, one participant acts as a marionette, while the other moves the marionette by pulling the imaginary strings attached to the joints. After rehearsing, the marionettes perform for the others. Noah is not watching and seems to pay no attention to performances, but he responds to the request to perform his own marionette with the assisting teacher. At first, the exercise seems impossible for him, and it turns into a mirror game. However, when the music is added (me playing Kabalevsky's Clowns on the piano), the exercise turns into a free improvisation. Noah becomes surprisingly present and starts to move in an expressive, open, and honest way. It seems that Noah opens himself up to a larger self, hands open, facing the teacher. Also, as if Noah were anticipating the end of the piece, he lets his arms come down just at the right moment with the music. He receives praise from his teacher and from me, as well as applause from his peers.
\end{abstract}

During the teaching experiment, it became evident that verbal communication highlighted his acknowledged difficulties. However, he was able to engage in non-verbal dialogue and interaction with the classroom teacher through movement, gestures and music. It seems that the joint activity kept him in the moment and even helped him take the initiative. He watched and followed the classroom teacher's movements and gestures and remained present during the interaction. Indeed, he became involved in a musical activity in a new way. In his free body-movement improvisation, he displayed imagination and expressiveness. His classroom teacher thought that Noah benefitted from the kind of mirror imitation exercises in which he could move close to the other person without touching. Both the classroom teacher and the special education specialist stressed the importance of repetition, anticipation of the situations, and familiarity of exercises in enabling Noah's participation. Indeed, repeating the exercises several times clearly supported Noah's participation. 
In one lesson, when repeating a previously rehearsed chain dance that Noah disliked, he takes the initiative and joins the dance, even though no one asks him to. He chooses his place in the middle of the chain, between the classroom teacher and the assistant. As the dance starts, Noah participates and concentrates fully. Surprisingly, when I ask him to lead the group, he agrees and looks very proud and confident to lead the chain! When the leader changes again, he moves to the other end of the chain and enjoys the increasing tempo of the dance. Everyone is laughing and trying to remain hand-inhand while whirling around. Noah seems to enjoy being an active participant in the group with varying roles.

This narrative illustrates the moment when Noah was able to actively participate in a shared musical activity with varying roles and responsibilities and even had the courage to lead the activity. In overall, towards the end of the teaching experiment, Noah became able and felt comfortable to interact socially with the others in and through body movement, instead of simply randomly touching them as though they were objects. As his classroom teacher noticed, his bodily orientation had changed toward the centre of the action. Clearly, he had found new ways to participate and communicate with the others, and he enjoyed it. According to the special education specialist's video observation of the chain dance, Noah had taken huge steps in his development and courage, and he had overcome his social anxiety and hypersensitivity in music-and-movement lessons.

His transformed, active agency was noticed afterwards by the teachers, assistants, and peers, even outside of the classroom. During the teaching experiment, Noah had bonded with the teacher, with whom he had done many music-and-movement exercises in pairs. Encouraged by this teacher, Noah, for example, had pulled a younger student in a sledge during the recess. In addition to this, his own classroom teacher and classmates had noticed that Noah hardly had any fits of rages anymore. His peers even gave him a 'golden key', which was nominated weekly by peers for the student who had succeeded that week. The argument for giving the key was: 'Because he has not raged that much anymore' He was awarded the key several times after that.

Noah was not able to reflect on his development of agency. It was even difficult for him to become aware and articulate his experiences. Yet, he could express some likes and dislikes. He reported he had found some of the exercises difficult, but in general his experiences were positive, even those including physical contact with the others. It was surprising that he had enjoyed the group activities since he usually prefers to do things alone. In the interview situation, he enjoyed watching himself in the video and had strong memories of the chain dance he had led, which suggests that succeeding in this activity had been a meaningful and empowering experience for him.

\section{Discussion}

The four episodes presented above, demonstrate a transformation in Noah's agency from a passive outsider and observer to an interactive participant and active leader. During the six-month teaching experiment, Noah gradually built body skills, gained self-confidence, and learned to deal with and overcome emotional tensions. Perhaps most importantly, Noah developed autonomy in and through his intersubjective relationships, showing an interdependence. The transformed capacities, such as nonverbal communication skills, opened up possibilities for a new kind of agency (see Mackenzie, 2009). He learned new ways to participate, interact, communicate, initiate, and control his own 
actions, and express himself in a meaningful way, which are all, according to the phenomenological perspective, considered essential in the development of agency.

In Noah's case, his Asperger's created a challenge for his development of agency (BaronCohen et al., 2001; Attwood, 2007). Noah's AS-driven repetitive motor patterns and mannerisms were present in his decision making, participation, and (inter)action in general (for repetitive behaviours in autism see Boyd, McDonough \& Bodfish, 2012). Noah overcame the challenges he had in terms of situating himself within the context associated with music, movement, and social interaction. In the beginning, Noah's bodily orientation was more focused on himself than on the others. Lacking social and emotional reciprocity, he could not understand complex, interactional situations, and he literally moved back and escaped to things and objects that he perceived safe for him. However, Noah's mannerisms gradually decreased, and he became able to participate and interact with others through non-verbal communication.

In line with earlier studies (Allgood, 2003; Darrow \& Armstrong, 1999), socially embedded musical activities provided Noah opportunities to engage in comfortable and predictable intersubjective encounters, whereby his attention and initiative in interaction increased (see also Wimpory, Chadwick \& Nash, 1995). Through sensorimotor exploration and engagement with others, Noah's body and social skills developed, and as a result, the other students could also better understand and accept him. Intersubjective relationships and experience of being accepted, in turn, appeared to support his self-esteem and enhanced his ability to be the author of his own actions, that is, his autonomy.

The music-and-movement exercises, especially the synchronized movements kept Noah present during the activity. When he participated in them, he had to constantly respond to and interact with the music and other students. In other words, the exercises helped Noah become attuned to the moment, music, and other students and to communicate with them. During improvisation exercises, he could express his experience of the music. Engaging in a joint action enabled Noah also to experience a shared sense of rhythmic timing and affective state (see Clayton, 2012; Phillips-Silver \& Keller, 2012). It was observable that the synchronized movements also increased group cohesion and social affinity overall. This echoes studies that suggest that the development of shared repertoires of movement, touch, and facial and vocal expression form the basis for social understanding (Hagen \& Bryant, 2003; Hove \& Risen, 2009).

Though we are aware of the fact that also other events and experiences in Noah's life during the experiment presumably influenced development of his agency, this study shows that a student with special needs can develop tools for agency in and through embodied musical interaction in a music classroom. The future will show whether the development of Noah's agency carries out further in other real-life situations and possibly in society at large. According to initial follow-up information, Noah is studying in a vocational college training programme, which supports students with SEN develop abilities to function as independently as possible in working life and to take responsibility of their own lives. Music plays a key role in Noah's life and he has started to sing while listening to his favourite music.

Even if it is not possible to make generalizations based on this study, we suggest that the kind of embodied exploration of music, oneself, and others that the Dalcroze-based approach offers, not only for students with special educational needs but for all students in music classrooms, possibilities to gain embodied musical knowledge, develop skills and creativity, express, interact through joint action and social relationships, build self-confidence and sense of self, among other 
things, and thus develop one's (musical) agency and a holistic growth. Therefore, the educational possibilities of such embodied interaction require further attention both in practice and research of (music) education and therapy.

\section{Conclusion}

Though music education in Finland, as education is relatively considered equal and accessible to everyone (FNBE, 2014), the choice of pedagogical approaches does not always support every student's meaningful participation. Music education still (too) often focuses on developing instrumental skills and emphasises virtuosity over holistic development and different ways of learning music. Therefore we should ask: To what degree, are we as music educators aware of the possibilities of embodied musical interaction to support student development and overall growth?

Proposed in this study and elsewhere (e.g., Altenmüller \& Scholz, 2016; Greenhead \& Habron, 2015; Juntunen \& Westerlund, 2001; Juntunen, 2004; 2016; Kressig, 2017; Treviño, 2018), the overall educational strength of Dalcroze-based teaching rests on that it incorporates, challenges, and activates several capabilities of the participant at the same time and requires constant responding in creative ways thus engaging a diverse range of mind-body. It promotes musical participation and interaction without requiring an ability to understand complex verbal directions, and allows making sense of the musical world, oneself, and others through bodily exploration and experience. As Schiavio (2018) suggests, embodied approaches that emphasize creativity, improvisation, and collaboration along with the body movements may better acknowledge the diverse (mind-)bodies in music teaching and learning. Learning happens in embodied relationship with the environment (Gallagher \& Lindgren, 2015), in which movement and interaction are crucial. This way music education can offer equal music learning opportunities for everyone, regardless of one's skills or abilities. Music teaching often takes place through verbal directions and requires rule-following ignoring that 'successful learning and action do not require propositional mental representations' (Dreyfus, 2002, p. 367). Furthermore, in music-and-movement lessons, the students can practice and develop their social and interaction skills in diverse ways, which support the development of agency. However, the process of development may take time, results may appear only after some time, or as in Noah's case, development may take unpredictable leaps during a short period of time. Furthermore, the positive effects are not automatic. They require, first and foremost pedagogical skillfulness, including ability to attend to students' individual needs, strengths, capabilities, and skills, and to act respectively. It also important for the teacher to be, interested in student experience.

As regards research and theory on agency, this article calls for a further examination of development of agency in music education contexts, and especially discussion of the relations between concepts of embodiment and agency. This is especially important, when discussing individual demands, that interfere with acting "rationally" and according to social standards. In this article, we have approached the notion of agency in a holistic way and wish to encourage other researchers to further study the complexity and richness of agency in music education contexts.

\section{References}


ABRIL, C. R. (2011) Music, movement, and learning. In R. Colwell \& P. R. Webster (Eds), The MENC Handbook of Research in Music Learning, Volume 2: Applications (pp. 92129). New York: Oxford University Press.

ALLGOOD, N. (2003) Music and sensory integration for children with autism spectrum disorders. Early Childhood Connect, 9, 21-27.

ALTENMÜLLER, E. \& SCHLAUG, G. (2015) Apollo's gift: New aspects of neurologic music therapy. Progress in Brain Research, 217, 237-252. http://doi.org/10.1016/bs.pbr.2014.11.029

ALTENMÜLLER, E. \& SCHOLTZ, D. S. (2016) Èmile Jaques-Dalcroze as a visionary pioneer of neurologic music therapy. Approaches: An Interdisciplinary Journal of Music Therapy, 8(2), 112-117.

AMERICAN PSYCHIATRIC ASSOCIATION. (2013) Diagnostic and Statistical Manual of Mental Disorders, (5th Edition, text revision). Washington, DC: American Psychiatric Association.

ATKINSON, P., COFFEY, A., DELAMONT, S., LOFLAND, J. \& LOFLAND, L. (2001) Handbook of Ethnography. London: SAGE Publications.

ATTRIDE-STIRLING, J. (2001) Thematic networks: An analytic tool for qualitative research. Qualitative Research 1(3), 385-405.

ATTWOOD, T. (2007) The Complete Guide to Asperger's Syndrome. London: Jessica Kingsley Publisher.

BANDURA, A. (1986) Social Foundations of Thought and Action: A Social Cognitive Theory. New Jersey: PrenticeHall.

BARON-COHEN, S., WHEELWRIGHT, J. H., RASTE, Y. \& PLUMB, I. (2001) The "reading the mind in the eyes" test revised version: A study with normal adults, and adults with Asperger syndrome or high-functioning autism. Journal of Child Psychology and Psychiatry, 42(2), 241-251.

BAUMAN, M. L. (1992) Motor dysfunction in autism. In A. B. Joseph \& R. R. Young (Eds), Movement Disorders in Neurology and Psychiatry, 1, 658-661.

BELLINI, S. (2004) Social skill deficits and anxiety in high-functioning adolescents with autism spectrum disorders. Focus on Autism and Other Developmental Disabilities, 19(2), 78-86.

BERA (BRITISH EDUCATIONAL RESEARCH ASSOCIATION). (2011) Ethical Guidelines for Educational Research.

https://www.bera.ac.uk/researchers-resources/publications/ethical-guidelines-foreducational-research-2011 (Accessed: 11 May 2019).

BERGER, D. S. (2015) Eurhythmics for Autism and Other Neurophysiologic Diagnoses: A

Sensorimotor Music-based Treatment Approach. London: Jessica Kingsley Publishers.

BOYD, B. A., MCDONOUGH, S. G., \& BODFISH, J. W. (2012) Evidence-based behavioral interventions for repetitive behaviors in autism. Journal of Autism Developmental Disorders, 42, 1236-1248.

BRAUN, V. \& CLARKE, V. (2006) Using thematic analysis in psychology. Qualitative Research in Psychology, 3(2), 77-101. 
BRAUN, V. \& CLARKE, V. (2012) Thematic analysis. In H. Cooper, P. M. Camic, D. L. Long, A. T. Panter, D. Rindskopf \& K. J. Sher (Eds), APA handbook of research methods in psychology, Vol.2. Research designs: Quantitative, qualitative, neuropsychological, and biological (pp. 57-71). Washington, DC: American Psychological Association.

BURROW, S. (2009) Bodily limits to autonomy: Emotion, attitude, and self-defense. In S. Campbell, L. Meynell \& S. Sherwin (Eds), Embodiment and Agency (pp. 126-144). University Park: The Pennsylvania State University Press.

BUXBAUM, J. \& HOF, P. (2012) (Eds), The Neuroscience of Autism Spectrum Disorders. Oxford: Academic Press.

CAMPBELL, S., MEYNELL, L. \& SHERWIN, S. (2009) Embodiment and Agency. University Park: The Pennsylvania State University Press.

CARTER, N., BRYANT-LUKOSIUS, D., DiCENSO, A., BLYTHE, J., \& NEVILLE, AJ. (2014) The use of triangulation in qualitative research. Oncology Nursing Forum, 41(5),545547.

CLAYTON, M. (2012) What is entrainment? Definition and applications in musical research. Empirical Musicology Review, 7(1-2), 49-56.

DARROW, A. A. (2014) Promoting social and emotional growth of students with disabilities. General Music Today 28(1), 29-32.

DARROW, A. A. (2018) Instructional strategies for the inclusive music classroom. General Music Today, 31(3), 61-65.

DARROW, A. A. \& ADAMEK, M. S. (2012) Preparing for the future: Music students special education needs in school and community life. In G. E. McPherson \& G. F. Welch (Eds) The Oxford Handbook of Music Education Vol 2, (pp. 81-98). New York: Oxford University Press.

DARROW, A. A. \& ADAMEK, M. S. (2017) Recent and continuing initiatives and practices in special education. Music Educators Journal, 104(2), 32-37.

DARROW, A. A. \& ARMSTRONG, T. (1999) Research on music and autism: implications for music educators. Update: Applications of Research in Music Education, 18, 15-20.

DAVIDSON, J. W. (2009) Movement and collaboration in musical performance. In S. Hallam, I. Cross \& M. Thaut (Eds) Oxford Handbook of Music Psychology, (pp. 364-376). Oxford: Oxford University Press.

DEWEY, J. (1897) My Pedagogic Creed. New York: E. L. Kellogg.

DEWEY, J. (1916) Democracy and Education: An Introduction to the Philosophy of Education. New York: Macmillan.

DENORA, T. (2002) Music in Everyday Life. Cambridge: Cambridge University Press.

DREYFUS, H. L. (2002) Intelligence without representation: Merleau-Ponty's critique of mental representation: The relevance of phenomenology to scientific explanation. Phenomenology and the Cognitive Sciences, 1, 367-383.

ENGESTRÖM, Y., MIETTINEN, R. \& PUNAMÄKI, R.-L. (1999) Perspectives on Activity Theory. Cambridge: Cambridge University Press.

FLAUGNACCO, E., LOPEZ, L., TERRIBILI, C., MONTICO, M., ZOIA, S. \& SCHÖN, D. (2015) Music training increases phonological awareness and reading skills in developmental dyslexia: A randomized control trial. PLOS ONE, 10(9), e0138715. doi: 10.1371/journal.pone.0138715 
FNBE (2016) National Core Curriculum for Basic Education 2016. Helsinki: Finnish National Board of Education.

GALLAGHER, S. (2000) Philosophical conceptions of the self: Implications for cognitive science. Trends in Cognitive Science, 4(1), 14-21.

GALLAGHER, S. (2012) Multiple aspects in the sense of agency. New Ideas in Psychology, 30(1), $15-31$.

GALLAGHER, S. \& LINDGREN, R. (2015) Enactive metaphors: Learning through full-body engagement. Educational Psychology Review, 27(3), 391-404.

GERETSEGGER, M., ELEFANT, C., MÖSSLER, K. A. \& GOLD, C. (2014) Music therapy for people with autism spectrum disorder. Cochrane Database of Systematic Reviews, 6 , CD004381. doi: 10.1002/14651858.CD004381.pub3

GIDDENS, A. (1984). The Constitution of Society. Berkeley: University of California Press.

GREENHEAD, K. \& HABRON, J. (2015) The touch of sound: Dalcroze Eurhythmics as a somatic practice. Journal of Dance \& Somatic Practices, 7(1), 93-112.

HABRON-JAMES, B. (2013) Mémoire de Diplôme: The Application of Dalcroze Eurhythmics to the teaching of children with special educational needs. Unpublished Diplome Superieur thesis. Geneva: Institut Jaques-Dalcroze.

HAGEN, E. \& BRYANT, G. (2003) Music and dance as coalition signaling system. Human Nature, 14(1), 21-51.

HALLAM, S. (2015) The Power of Music: A Research Synthesis on the Impact of Actively Making Music on the Intellectual, Social and Personal Development of Children and Young People. London: International Music Education Research Centre.

HALLAM, S. (2016) The impact of actively making music on the intellectual, social and personal development of children and young people: A summary. Voices: A World Forum for Music Therapy, 16(2). doi:10.15845/ voices.v16i2.884

HAMMEL, A.M. \& HOURIGAN, R. (2011) Teaching Music to Students with Special Needs: A Label-free Approach. New York: Oxford University Press.

HOVE, M.J. \& RISEN, J.L. (2009) It's all in the timing: Interpersonal synchrony increases affiliation. Social Cognition, 27, 949-961.

HUSS, M., VERNEY, J.P., FOSKER, T., MEAD, N. \& GOSWAMI, U. (2011) Music, rhythm, rise time perception and developmental dyslexia: Perception of musical meter predicts reading and phonology. Cortex, 47(6), 674-689.

IPU (1998) Democracy: Its Principles and Achievement. Geneva: Inter-Parliamentary Union. http://archive.ipu.org/PDF/publications/DEMOCRACY_PR_E.pdf

JAQUES-DALCROZE, É. (1921/1980) Rhythm, music and education. London, UK: Dalcroze Society.

JOHNSON, M. \& ROHRER, T. (2007) We are live creatures: Embodiment, American pragmatism, and the cognitive organism. In J. Zlatev, T. Ziemke, R. Frank, R. Dirven (Eds), Body, Language, and Mind, Vol.1 (pp. 17-54). Berlin: Mouton De Gruyter.

JUNTUNEN, M.-L. (2002) The practical applications of Dalcroze Eurhythmics. Nordic Research in Music Education Yearbook, 6, 75-92.

JUNTUNEN, M.-L. (2004) Embodiment in Dalcroze Eurhythmics. Doctor's thesis. Oulu: University of Oulu. http://jultika.oulu.fi/Record/isbn951-42-7402-4 
JUNTUNEN, M.-L. (2015) Pedagoginen kokeilu integroida Ipadin käyttö, luova tuottaminen ja keholliset työtavat peruskoulun seitsemännen luokan musiikinopetuksessa. Tapaustutkimus toimijuuden näkökulmasta [Pedagogical experiment on the use of iPads with creative production and bodily approaches in 7 thgrade music instruction. A case study from the perspective of agency]. Finnish Journal of Music Education, 18(1), 56-76.

JUNTUNEN, M.-L. (2016) The Dalcroze approach: Experiencing and knowing music through the embodied exploration. In C. R. Abril \& B. Gault (Eds), Approaches to Teaching General Music: Methods, Issues, and Viewpoints (pp. 141-167). New York: Oxford University Press.

JUNTUNEN, M.-L. \& Eisenreich, C. (2019) Assessment in the Dalcroze pedagogy. In T. S. Brophy (Ed) Handbook of Assessment Policy and Practice in Music Education, Volume 2: The United States, Classroom Practice, and Technology. Part 2: The Assessment of Classroom Music Learning, Chapter 23 (pp. 561-590). New York: Oxford University Press.

JUNTUNEN, M.-L. \& HYVÖNEN, L. (2004) Embodiment in musical knowing: How body movement facilitates learning within Dalcroze Eurhythmics. British Journal of Music Education, 21(2), 1-16.

JUNTUNEN, M.-L. \& WESTERLUND, H. (2001) Digging Dalcroze, or, dissolving the mind-body dualism: Philosophical and practical remarks on the musical body in action. Music Education Research, 3(2), 203-214.

KAlliO, H., PIETILÄ, A.-M., JOHNSON, M. \& KANGASNIEMI, M. (2016) Systematic methodologial review: Developing a frameworld for a qualitative semi-structured interview guide. Journal of Advanced Nursing, 72, 2954-2965. doi: 10.111/jan.13031

KAMP-BECKER, I., SMIDT, J., GHAHREMAN, M., HEINZEL-GUTENBRUNNER, M., BECKER, K. \& REMSCHMIDT, H. (2010) Categorical and dimensional structure of Autism Spectrum Disorders: The nosologic validity of Asperger Syndrome. Journal of Autism and Developmental Disorders, 40(8), 921-929.

KARLSEN, S. (2011) Using musical agency as a lens: Researching music education from the angle of experience. Research Studies in Music Education, 33(2), 107-121.

KIRSCHNER, S. \& TOMASELLO, M. (2010) Joint music-making promotes prosocial behavior among four-year old children. Evolution and Human Behavior, 31, 354-364.

KLIN, A., VOLKMAR, F. R. \& SPARROW, S. S. (2000) (Eds) Asperger Syndrome (pp. 340-66). New York: Guilford Press.

KOGGEL, C. (2009) Agency and empowerment: Embodied realities in a globalized world. In S. Campbell, L. Meynell \& S. Sherwin (Eds), Embodiment and Agency (pp. 250-268). University Park: The Pennsylvania State University Press.

KRESSIG, R. W. (2017) Music, Movement and the Brain. Keynote presentation. The third conference of Dalcroze studies, Quebec, August 2017.

LAES, T. (2015) Empowering later adulthood music education. A Case study of a rock band for third age learners. International Journal of Music Education 33(1), 51-65. doi: $\underline{10.1177 / 0255761413515815}$ 
LAES, T. (2017) The (Im)possibility of Inclusion. Reimagining the Potentials of Democratic Inclusion in and through Activist Music Education. Studia Musica 72. Helsinki: Sibelius Academy of the University of Arts Helsinki.

LAKOFF, G. \& JOHNSON, M. (1999) Philosophy in the Flesh: The Embodied Mind and Its Challenge to Western Thought. New York: Basic Books.

LAMB, S. J. \& GREGORY, A. H. (1993) The relationship between music and reading in beginning readers. Educational Psychology: An International Journal of Experimental Psychology, 13(1), 19-27.

LONG, M. (2014) 'I can read further and there's more meaning while I read': An exploratory study investigating the impact of a rhythm-based music intervention on children's reading. Research Studies in Music Education, 36(1), 107-124.

MÄ̈̈TTÄNEN, P. (2015) Mind in Action: Experience and Embodied Cognition in Pragmatism. Cham: Springer.

MACKENZIE, C. (2009) Personal identity, narrative integration, and embodiment. In S. Campbell, L. Meynell \& S. Sherwin (Eds), Embodiment and Agency (pp. 100-125). University Park: The Pennsylvania State University Press.

MADDOX, B. B. \& WHITE, S. W. (2015) Comordid social anxiety disorder in adults with autism spectrum disorder. Journal of Autism and Developmental Disorders, 45(12), 39493960.

MAES, P.-J. (2016) Sensorimotor grounding of musical embodiment and the role of prediction: A review. Front Psychology, 7, 1-10.

MARSH, K. L., RICHARDSON, M., \& SCHMIDT, R. C. (2009) Social connection through joint action and interpersonal coordination. Topics in Cognitive Science, 1, 320-339.

MATSON, J \& STURMEY, P. (2011) (Eds) International Handbook of Autism and Pervasive Developmental Disorders. London: Springer.

MATYJA, J. R. \& SCHIAVIO, A. (2013) Enactive music cognition: Background and research themes. Constructivist Foundations, 8(3), 351-357.

MERLEAU-PONTY, M. (1962) Phenomenology of Perception. London: Routledge.

MEYERS, D. (2004) Being Yourself: Essays on Identity, Action, and Social Life. Lanham: Rowman $\&$ Littlefield.

MEYNELL, L. (2009) Introduction: Minding bodies. In S. Campbell, L. Meynell \& S. Sherwin (Eds), Embodiment and Agency (pp. 1-24). University Park: The Pennsylvania State University Press.

MORAN, N. (2018) Agency in embodied interaction. In M. Leman, M. Lesaffre \& P.-J. Maes (Eds) The Routledge Companion to Embodied Music Interaction (pp. 105-112). New York: Routledge.

OCKELFORD, A. (2015) The Sounds of Intent Project: Modelling musical development in children with learning difficulties. Tizard Learning Disability Review, 20(4), 179-194.

OECD (2012) Equity and Quality in Education: Supporting Disadvantaged Students and Schools. Paris: OECD Publishing. http://dx.doi.org/10.1787/9789264130852-en

OVERY, K. (2008) Classroom rhythm games for literacy support. In T. Miles., J. Westcombe \& D. Ditchfield (Eds), Music and Dyslexia: A Positive Approach (pp. 26-44). Chichester: John Wiley and Sons. 
OVERY, K. \& MOLNAR-SZAKACS, I. (2009) Being together in time: Musical experience and the mirror neuron system. Music Perception: An Interdisciplinary Journal, 26(5), 489504. 10.1525/mp.2009.26.5.489

PACHERIE, E. (2010) Self-agency. In S. Gallagher (Ed), The Oxford handbook of the self (pp. 440462). Oxford: Oxford University Press.

PESSOA, L. (2008) On the relationship between emotion and cognition. Nature Reviews Neuroscience, 9(2), 148-158.

PESSOA, L. (2009) How do emotion and motivation direct executive control? Trends in Cognitive Sciences, 13(4), 160-166.

PHILLIPS-SILVER, J. \& KELLER, P. E. (2012) Searching for roots of entrainment and joint action in early musical interactions. Frontiers in Human Neuroscience, 6(26). doi:10.3389/fnhum.2012.00026

PIPPIN, R. B. (2008) Hegel's Practical Philosophy: Rational Agency as Ethical Life. Cambridge: Cambridge University Press.

POLKINGHORNE, D. E. (1995). Narrative configuration in qualitative analysis. International Journal of Qualitative Studies in Education, 8(1), 5-23.

SCOTT, S. J. (2017) Music Education for Children with Autism Spectrum Disorder: A Resource for Teachers. New York: Oxford University Press.

SEAWRIGHT, J. \& GERRING, J. (2008) Case selection techniques in case study research: A menu of qualitative and quantitative options. Political Research Quarterly 61, 294-308.

SHAPIRO, L. (2010) Embodied Cognition. New York: Routledge.

SPAIN, D., HAPPE, F., JOHNSTON, P., CAMPBELL, M., SIN, J. \& DALY, E. (2016) Social anxiety in adult males with autism spectrum disorders. Research in Autism Spectrum Disorders, 32, 13-23.

SRINAVASAN, S. M. \& BHAT, A. N. (2013) A review of "music and movement" therapies for children with autism: Embodied interventions for multisystem development. Frontiers in Integrative Neuroscience, 7(22), 1-15.

STAKE, R. E. (1995) The Art of Case Study Research. Thousand Oaks: Sage.

STRAIT, D. L., HORNICKEL, J. \& KRAUS, N. (2011) Subcortical processing of speech regularities underlies reading and music aptitude in children. Behavioral and Brain Functions, 7, 44.

STOCKER, M. \& HEGEMAN, E. (1996) Valuing Emotions. New York: Cambridge University Press.

TENK (2012) Responsible Conduct of Research and Procedures for Handling Allegations of Misconduct in Finland. Helsinki: Finnish Advisory Board on Research Integrity. http://www.tenk.fi/sites/tenk.fi/files/HTK_ohje_2012.pdf

THALBERG, I. (2014) Enigmas of Agency: Studies in the Philosophy of Human Action. Abingdon: Routledge.

TREVIÑO, E. (2018). Efectos de la de rítmica Jaques-Dalcroze en variables psicológicas y físicas. Doctor's thesis. Monterrey: Autonomous University of Nuevo León.

TSAKIRIS, M., LONGO, M. R. \& Haggard, P. (2010) Having a body versus moving your body: Neural signatures of agency and body-ownership. Neuropsychologia, 48(9), 27402749. 
TRYFON, A., FOSTER, N. E., OUIMET, T., DOYlE-THOMAS, K., ANAGNOSTOU, E., SHARDA, M. \& HYDE, K. L. (2017) Auditory-motor rhythm synchronization in children with autism spectrum disorder. Research in Autism Spectrum Disorders, 35, $51-61$.

UNESCO (1994) Final Report: World Conference on Special Needs Education: Access and Quality. Paris: UNESCO.

UNESCO (2007) A Human Rights-Based Approach to Education for All: A framework for the realization of children's right to education and rights within education. New York: United Nations.

VAN MANEN, M. (1990) Researching Lived Experience. New York: State University New York.

VAN MANEN, M. (2016) Phenomenology of Practice: Meaning-giving methods in phenomenological research and writing. New York: Routledge.

VAN DER MERWE, L. (2015) The first experiences of music students with Dalcroze-inspired activities: A phenomenological study. Psychology of Music, 43(3), 390-406.

VYGOTSKY, L. (1978) Interaction between learning and development. In M. Gauvain \& M. Cole (Eds), Readings on the Development of Children (pp. 34-40). New York: Scientific American Books.

WANG, D. P.-C. (2008) The quantifying analysis of effectiveness of music learning through the Dalcroze musical method. US-China Education Review, 5(9), 32-41.

WHIPPLE, J. (2004) Music intervention for children and adolescents with autism: A meta-analysis. Journal of Music Therapy, 41(2), 90-106.

WIGRAM, T. \& GOLD, C. (2006) Music therapy in the assessment and treatment of autistic spectrum disorder: Clinical application and research evidence. Child: Care, Health and Development, 32(5), 535-542.

WIMPORY, D., CHADWICK, P., \& NASH, S. (1995) Brief report: Musical interaction therapy for children with autism: An evaluative case study with two-year follow-up. Journal of Autism and Developmental Disorders, 25, 541-552.

WORLD HEALTH ORGANIZATION. (1993) The ICD-10 classification of mental and behavioural disorders: diagnostic criteria for research. Geneva: World Health Organization.

YAKHLEF, A. (2010) The corporeality of practice-based learning. Organization Studies, 31(4), 409430.

YIN, R. K. (2003) Case Study Research: Design and Methods. Thousand Oaks: Sage.

\footnotetext{
i This study is partially funded by the ArtsEqual research initiative which is in turn funded by the Academy of Finland's Strategic Research Council from its Equality in Society programme (project no. 293199). Of the authors, Juntunen works under the auspices of the ArtsEqual initiative, while Sutela and Ojala are members of the Community of Research in Education, Music, and the Arts (CREMA), at the University of Oulu, Finland.

ii Asperger syndrome is a chronic and serious neurodevelopmental disorder. It is defined by social and communicative deficits and restricted interests, as seen in the autistic spectrum. It also means challenges in cognitive abilities and language (Klin, Volkmar \& Sparrow, 2000; Attwood, 2007). Asperger syndrome and autism are different manifestations of the same disorder (see, Kamp-Becker et al., 2010). The current diagnostic criteria distinguish AS from autism primarily via exclusionary criteria (APA, 2013; WHO, 1993): two areas of impairment in social behavior co-occurring with restricted and repetitive patterns of interests and behavior (Buxbaum \& Hof, 2012). Individuals with ASD worry about social situations and suffer from anxiety (see Bellini, 2004; Maddox and White, 2015; Spain et al.,
} 
2016). Impairments of their ability to recognize and understand others' mental states (Baron-Cohen et al., 2001) may even contribute to the development of one's agency.

iii These approaches (like Dalcroze) promote the use of body movements to understand musical elements like rhythms, harmony and melody, and whole body rhythmic actions such as clapping, walking to music and expressive movements. 